\title{
Open conflict as differentiation strategy in geographical indications: the Bitto Rebels case.
}

\author{
Diego Rinallo ${ }^{\mathrm{a}}$, Valentina Pitardi $\mathrm{b}^{*}$
}

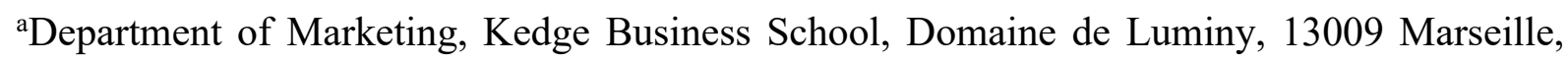
France

${ }^{b}$ Department of Marketing and Sales, Porthsmouth Business School, University of Porthsmouth, Richmond Building, Portland St, Portsmouth PO1 3DE, UK.

* Corresponding author

E-mail addresses:diego.rinallo@kedgebs.com (D. Rinallo), valentina.pitardi@port.ac.uk (V. Pitardi). 


\begin{abstract}
Purpose: This paper investigates how open, mediatised conflict in geographical indications can provide the basis for differentiation strategies for heritage producers based on both functional and symbolic benefits.
\end{abstract}

Design/methodology/approach: Longitudinal case study, based on multiple data sources, which reconstructs the history of the Bitto geographical indications and the conflict between the PDO Bitto Consortium and a small number of heritage Bitto producers.

Findings: The paper highlights how the mediatised narration of conflict can contribute to raise consumer awareness, differentiate products, and result in symbolic value creation.

Research limitations/implications: Extreme case study design, purposively chosen as characterised by conditions likely to accentuate conflict.

Practical implications: The paper develops a conceptual framework that permits to identify the potential for conflict inside geographical indications. It also contributes to a better understanding of the image of products protected by geographical indications and the role played by heritage producers. It also offers practical advice on two promotional tools, namely trade fair participations and experiential showcases.

Social implications: The paper offers practical advice on the safeguarding of small producers localised in cultural epicentres inside geographical indications. 
Originality/value: We introduce the notions, such as competitive wars and secession, that contribute to a better understanding of centripetal/centrifugal forces inside geographical indications. We also propose a better understanding of image creation of geographical indications, grounded in cultural work in marketing and consumer research.

Keywords: Geographical Indications, conflict, longitudinal case study, Bitto cheese, competitive wars, experiential showcases, taste education, storytelling, differentiation strategy.

Type: Research Paper 


\section{Open conflict as differentiation strategy in Geographical Indications: \\ The Bitto Rebels case}

\section{Introduction}

Geographical indications (hereafter GIs) identify products originating in a specific territory, whose specificity is based on local characteristics, expertise and knowledge (Addor et al., 2003; Vandercandelaere et al., 2010; Reg. 1151/12; i.e. “GEO-Regulation”). For producers, GIs represent a valuable opportunity to differentiate their products from the competition and prevent the use of the GI or the product's name for goods not originating from the reference territory (Addor and Grazioli, 2002). From a marketing perspective, GIs act as quality signals for both distribution channels and consumers, thus facilitating access to domestic and foreign markets. GIs are a driver of consumer preference and purchase intention (Krystallis and Ness, 2005), allowing producers and retailers to sell products protected by GIs at higher prices. Several studies have investigated consumers' reactions to GIs, showing that consumers perceive these products as of higher quality (van Ittersum et al. 1999, 2007; Hoffmann, 2000; Mérel and Sexton, 2012), evaluate them as more authentic and traditional (Tregear et al., 2007), and are willing to pay a premium price respect to place-less products (Allaire et al., 2011; Agostino and Trivieri, 2014).

Overall, marketing literature focuses on consumer responses to GIs, which can be seen as the bases for a successful differentiation strategy. According to Porter (1985), differentiation is one possible strategy to achieve a sustainable competitive advantage. In a differentiation strategy, firms seek to be unique in their market along some dimensions that are valued by customers; because of their superiority in this respect, they are rewarded with a premium price. 
Differentiation can be based on functional and/or symbolic benefits (Park et al., 1986; Keller, 2003): the former correspond to objective product features, whereas the latter refer to non product-related attributes related to consumer needs for social approval and personal expression. Other streams of research have examined the social, economic, and environmental impacts of GIs for local communities (Rangnekar, 2004; Van de Kop et al. 2006; Traegar et al. 2007; Bowen, 2010). The picture emerging from this literature suggests that GIs can be a mixed blessing: for example, the market success of GI-protected products may lead to greater production volumes, which might lead to negative environmental impacts and changes to production methods to obtain economies of scales. The limited work focusing on the processes leading to the establishment of GIs (see, among others, Boisseaux and Barjolle, 2004; Boisseaux, 2012; Di Fonzo and Russo, 2015) shows that these processes are intrinsically political, requiring mediation between parties with different priorities and a balance between economic and cultural considerations. Before a product can be granted a GI protection, producer groups have to agree on product specifications. The specification is a document that lays down the production rules for the product to be protected by a GI. It includes a detailed description of the product's physical, chemical, microbiological and organoleptic features; the boundaries of the area of production; and the technical description of the production process. The process that leads to the establishment of product specification is often controversial and can sometimes lead to open conflicts. Controversies often remain at the level of argument or disagreements and can be seen as specific instances of conflict (Tjosvold, 1985; Wall and Callister, 1995). Conflict is therefore a broader concept that includes, but also extend beyond, controversies.

In this paper, we contribute to the limited literature addressing conflict, tensions and controversies in GIs (Moity Maïzi and Bouche, 2011; Di Fonzo and Russo, 2015; Amilien and 
Kjærnes, 2017) with a longitudinal case study, that of Bitto cheese. We qualify our study as one of conflict, rather than simple controversy, as narratives of conflict are prevalent in our informants' understanding of the so-called "Bitto wars". Additionally, from a theoretical perspective, our paper is based on a cultural understanding of marketing and consumer research (Arnould and Thompson, 2005), which has adopted conflict (and not controversies) as a central category for the analysis of marketplace dynamics (Luedicke, Thompson and Giesler, 2010; Husemann and Luedicke, 2013; Husemann, Ladstaetter and Luedicke, 2015). Our study shows that, sometimes, GIs do not protect adequately small, heritage producers localised in the product's area of origin. Faced with the extension of the production area and remarkable changes in the production process as well as a lack of recognition in the product specification of different quality levels differentiating heritage Bitto from its more industrialised counterpart, a small group of producers (the so-called Bitto Rebels) left the GI consortium to establish a Slow Food Presidium with product specifications more in line with traditional production processes and areas. No longer allowed to use the term Bitto to refer to their product despite being localised in the Bitto valleys, these producers have renamed their product 'Historical Rebel'. Notably, the open and highly mediatised rebellion has contributed to highlight differences between consortium-certified Bitto and Slow Food-sanctioned heritage Bitto, resulting in much higher sales price for the latter. By analysing the Bitto case study, this paper explores how divergences and controversies among the different actors involved in GIs systems may act as catalysts of mobilisation processes to safeguard heritage products. More importantly, we show that open conflict may serve as the base for a differentiation strategy, resulting in higher product awareness and premium price. 
The paper is organised as follow. First, we introduce the theoretical background of our study, highlighting differences in GIs and their product specifications that are more likely to result in the kind of open conflict that our empirical case is about, and proposing that mediatised conflict can provide the bases for a product differentiation strategy. We continue with a description of our research methodology, grounded in a longitudinal case study approach, followed by our research findings of the history and promotional uses of conflict in the Bitto case. We conclude with a discussion on the implications of our study.

\section{Conflict in Geographical Indications}

GIs are based on collective action. To be granted a GI, groups of producers first need to define the product according to precise specifications. Because of heterogeneity in production methods among producers, this process is inherently problematic and can originate controversies and conflicts. The adopted product specifications are the outcome of extensive negotiations and compromises. EU regulations distinguish between two different GIs: PDO, Protected Designation of Origin, and PGI, Protected Geographical Indication. Deciding whether applying for one or the other of these quality schemes can be already a source of conflict among differently minded producers. PGIs are based on local know-how and a close link between a product and the local area, but do not require that all stages of production, processing or preparation take place in the area. PDOs have instead a stronger link to the territory, requiring that all aspects of production, processing and preparation be local.

A possible conceptual framework to make sense of GIs is to distinguish them based on two dimensions: geographical area and production methods. The geographical area defines the territory of origin of the product (Addor et al. 2003). Its delimitation represents a fundamental 
prerequisite to obtain a GI protection. Only producers localised within the boundaries of the defined area will be protected by the GI. Geographical area can be restricted to the place of origin of a given product or enlarged to areas not traditionally associated to the product. For example, Taleggio is a PDO cheese named after the eponymous town in Lombardy, but today the production area of Taleggio include most of Lombardy and some areas in Piedmont (the provinces of Novara and Verbanio-Cusio-Ossola) and Veneto (the province of Treviso, which is not geographically contiguous to Lombardy). In contrast, the PDO lard of Arnad, can only be produced in the eponymous municipality in the Aosta Valley (28.84 sq.m. of surface, 1,271 inhabitants in 2017). Production methods refer to the traditional know-how, competences and skills necessary for the production of a given product in a specific territory. Only producers respecting the agreed-upon methods are allowed to sell their products under the GI trademark. Specifications for production methods can impose strictly defined traditional methods, or allow for production techniques that deviate to a smaller or larger extent from tradition. For example, the PDO Valais rye bread should be made from at least 90\% rye flour. Traditionally, only rye flour was employed to make bread in the Swiss Canton of Valais, so this constitutes a minor deviation from traditional production methods.

In sum, GI specifications may either confirm and safeguard the traditional territories and methods, or allow for larger area of production and not-traditional techniques. By considering the degree of change allowed, is it possible to develop a $2 \times 2$ matrix that identifies four possible situations (see Fig. 1). The two dimensions are to be considered as a continuum (that is, production areas can be more or less restricted; production methods can be more or less traditional) and oversimplify much more complex economic and social realities. A third relevant dimension, difficult to represent in a matrix, is the possible recognition of different 
production methods, more or less linked to tradition, in the product specifications. This is the case for example of Beaufort cheese from Savoie, which comes in three varieties: a more industrialised version produced in larger quantities, made in the lowlands (Beaufort); one made with milk coming from alps but processed in lowland dairies (Beaufort d'été); and a premium price version, produced in limited quantities during the summer by individual farmers in their alps (Beaufort Chalet Alpage).

\section{--- INSERT FIG 1 HERE ---}

Fig.1 GIs' product specifications: a conceptual framework

In terms of our proposed framework, product specifications can give origin to various forms of controversies and conflicts. Producers outside of the boundaries of a restricted production area might protest and exert their influence to be included. Conversely, more extended production areas may weaken the link between a product and its territory, triggering negative reactions from producers localised in its place of birth. Strict observance of traditional methods may inhibit innovation and result in higher costs and sales prices. Allowing for production methods that deviate from tradition may result in changes to product taste and a loss in authenticity. Whether product specification should allow for different production methods, like in the case of Beaufort, is another decision that can trigger tensions and conflicts. Producers who deviate from tradition might fear that publicly recognising different quality levels might devalue their products. Traditional producers might on the other hand insist on the superiority of their cultural heritage-consistent products. On these and related issues, different points of views, backed by economic, cultural, social and political considerations, can be maintained (Boisseaux and Lereche, 2002; Boisseaux, 2012). The resulting controversies are not necessarily dysfunctional. 
Differences in opinion can be met with open-minded consideration or with closemindedness and rejection (Tjosvold 1985). In the latter case, controversies that might have been productive can turn into destructive conflicts, and some members who feel damaged might question their adherence to the collective project represented by the GI. As long shown by research on membership in organization (Hirschmann, 1970), when benefits decrease and communication does not work, the only available course of action is withdrawing.

In this sense, heritage producers (those who adopt methods more in line with traditional methods, upper left quadrant of Fig. 1) sometimes need to resort to alternative quality certification systems. For example, producers of the PDO Chianti Classico wine, localized in a restricted production area of 14 municipalities between Florence and Siena, have a different GI respect to that of Chianti, whose production can take place in a much larger area. Similarly, producers of the PDO Traditional Balsamic Vinegar of Modena have a product specification imposing more artisanal production methods respect to the more industrialized PGI Balsamic Vinegar of Modena. Another case in point is the Taleggio cheese PDO. Producers from the Taleggio valley (who represent a minority in the Consortium for the Safeguarding of Taleggio cheese) have long tried to obtain some form of symbolic or financial compensation for being the place of birth of Taleggio, but without results. With the help of the Slow Food movement, some of these producers have revived an older, pre-industrial variety of Taleggio, naming it Stracchino (Grasseni, 2017; AlpFoodway, 2018). Slow Food (Jones et al., 2003; Siniscalchi, 2013) often cooperates with traditional producers to propose heritage versions of PDO-PGI products (AlpFoodway, 2018). This is for example the case of the Traditional Valais Rye bread (the Slow Food version, produced only by the Arnold bakery in Simplondorf, used $100 \%$ rye 
bread with sourdough starter that has been handed down for at least four generations in the baker's family).

\section{The mediatisation of conflict as a differentiation strategy}

Conflicts and controversies in GIs are often very well known by insiders but rarely reach consumers. When groups of producers link themselves to alternative quality certification schemes, conflict becomes visible, and even more so when it entails a formal secession from a PDO/PGI consortium. The mediatisation of conflict can result in greater consumer awareness of differences in production methods and areas and thus serve as a basis for a differentiation strategy (Porter, 1985). Indeed, trough mediatised conflict, heritage producers can not only highlight objective differences in production methods and area (functional differentiation) but also highlight symbolic differences linked to the fact that they produce heritage products that rebel against mainstream agrobusiness practices (symbolic differentiation). Mediatised conflict can also result in the circulation of stories that affect the image of all the actors involved. From a cultural perspective (McCracken, 1986; Arnould and Thompson, 2005), product meaning is co-created not only by producers but also by consumers, the media, NGOs, and other actors. Stories are powerful sources of brand meaning that spur imagination and emotional connections (Bruner, 2004; Escalas, 2004). Brand associations can be thought of as the residue of these stories (Holt, 2003).

Stories of rebellion, in particular, are powerful sources of product meaning that can fascinate and attract new consumers (Schouten and McAlexander, 1995; Heath and Potter, 2004). When framed as insurrection against larger, mainstream producers, narratives of conflict and rebellion may lead to consumer preference (Paharia et al., 2014). This is often referred to as the underdog 
effect: a marketing strategy based on a historical account of the lack of resources and determined struggle against the odd through firm biography (Paharia et al., 2010). Beyond consumer impacts, research on social conflicts shows that opposition to a 'common enemy' fosters the collective identity and vitality of the rebel group, also contributing to community boundaries maintenance (Muniz and O’Guinn, 2001; Husemann et al., 2015).

To sum up, mediatised conflict may form the basis for a differentiation strategy for smaller, heritage products based on consumers' perceived benefits. Given the increased consumer scepticism towards industrially produced food (e.g., Eden et al., 2008), this functional and symbolic differentiation strategy, whether planned or emerging, may contribute to justify the higher production prices of heritage producers (AlpFoodway, 2018) and contribute to find a niche market for these products. Research on GIs has so far not highlighted how mediatised conflict might result in a distinct, and potentially effective, market positioning that can contribute to safeguard heritage products, resulting in higher consumer awareness and willingness to pay. In this paper, we explore these notions through the emblematic case of the Bitto cheese.

\section{Methodology}

This paper is based on a longitudinal case study design, a well-established qualitative research method (Stake, 1995) that is particularly useful in food studies (Lyons, 2005; Tell et al., 2016). Case studies are particularly suitable to answer "how" and "why" questions and allow to address explorative examinations with the aim of producing a first-hand understanding of phenomena within complex and real-life context (Yin, 2014). As this paper aims to investigate how conflicts can lead to differentiation strategies for heritage producers, a case study approach 
seems most appropriate and effective in developing contributions to an inadequately understood phenomenon (Stake, 1995). Moreover, the scarcity of studies in this particular field of research calls for more in-depth and qualitative methods and a single case study may be suitable to investigate deeply in the new phenomenon.

The selection of the case study was based on the "opportunity to learn" (Sake, 1995, p. 57). Bitto represents an interesting and extreme case of controversy that could help enlighten the focus of this investigation. Yin (2014) further suggests that in cases of insufficient theoretical understanding of a phenomenon, cases should be selected based on their potential for theory building (Yin, 2014). In terms of our conceptual framework (see again Figure 1), our case is characterized by the highest potential of conflict from the perspective of heritage producers (extended production area, more industrialized production methods; no recognition of different quality levels) and, as such, can permit to more easily observe conflict dynamics and outcomes respect to cases of conflict that remains behind closed doors.

Case study research involves multiple sources of evidence (Yin, 2014). Data sources were selected to provide insight to the key elements of the study (see Table 1 for an overview). First, to document the history of the conflict that led heritage Bitto producers to abandon the PDO consortium and establish a Slow Food Presidium more in line with their production philosophy, we relied on published work on the topic (e.g., Corti and Ruffoni, 2009; Corti, 2011, 2015; Grasseni, 2011, 2012) as well as news stories and other material appeared in the press and on online sources. Overall, we gathered 217 news stories appeared in the period 2003-2018 on the national and local press, as well as on selected online portals that followed the Bitto wars. Second, to analyse the promotional use of conflict stories, we analysed the heritage Bitto 
promotional website ${ }^{\mathrm{I}}$, Facebook page ${ }^{\mathrm{II}}$, blog ${ }^{\mathrm{III}}$, Instagram channel (\#storicoribelle), as well as video-interviews given by the rebels and publicly available on youtube and other channels. We supplemented these sources with ethnographic observations of Bitto Rebel's promotional activities carried out by the first author during two trade fairs organised by the Slow Food movement, namely Cheese (Bra, near Turin, 15-18 September 2017) and Salone del Gusto (Turin, 20-24 September 2018), where we also gathered relevant printed promotional material. We also analysed consumer reviews of the Bitto Centre in Gerola ${ }^{\mathrm{IV}}$. Finally, we gathered information about sales prices of Bitto cheese from a variety of sources, including visits to retailers' online and offline sites. These data were supplemented by a limited number of interviews with some of the Bitto rebels during trade fairs and, in a more structured manner, through follow-up interviews.

\section{--- INSERT TABLE 1 HERE ---}

Table 1- Summary of main data sources

As better specified in Table 1, these complementary data sources served different purposes in the context of the present study. Our interpretive research strategy had the goal to reconstruct the story of the Bitto wars from the point of view of their protagonists, the Rebels, as well as the different manners consumers and other observers made sense of each. Our longitudinal approach allowed us to reconstruct the different stages in the history of the conflict surrounding Bitto, which we report in the first part of the next paragraph (A history of the Bitto wars). In the second part of our case study (Differentiating Heritage Bitto through a mediatised narrative of conflict), we reconstructed the emerging promotional strategy of the Rebels' heritage Bitto as well as the responses of consumers and other observers to such strategy. Coherently with an 
interpretive approach, we did not aim for triangulation of data sources to cross-validate them. We rather attempted to let divergence in perspectives emerge, for example when we note how a part of the public opinion initially perceived the Bitto Rebels approach as primitive or anachronistic, or when we highlight how according to some consumer the higher prices of heritage Bitto are not justified and constitute an elitist approach to food production. Given the nature of study that looks at the conflict opposing the Bitto Rebel to the Consortium, we did not make any attempt to contact the PDO Bitto consortium. We acknowledge that our findings predominantly document the story of Bitto from the vantage point of the Rebels, and that different actors and stakeholders might hold different, and equally valuable, points of views.

\section{Bitto Case study}

\section{A history of the Bitto wars}

The history of Bitto is linked to Alpine transhumance, the seasonal droving of cattle between the lowlands in winter and the high mountain pastures (alps) in summer carried out by caricatori d'alpe (those who would 'load' alps with cattle from various owners, taking care of milking cows and producing cheese). Both the cheese and its place of birth, the Bitto Valleys, owe their name to the Bitto creek, a small tributary to the Adda river that crosses the municipalities of Gerola and Albaredo in Valtelline (Sondrio province, Lombardy). Bitto cheese has been produced since at least the fifteenth century. Praised for its high quality, it was chosen as the representative product of Valtelline during the national exhibition celebrating the unification of Italy (Florence, 1861). Some Bitto producers attended with a collective presentation the 1906 Milan Expo, and the year after the first edition of the Morbegno fair, entirely dedicated to Bitto and 'Bitto-like' cheeses, took place. Bitto-like cheese was produced with similar techniques in high mountain pastures areas bordering the Bitto Valleys. Already 
in that occasion, the presence of different Bitto cheese categories triggered tensions and conflicts.

In 1908, the Società dei Caricatori d'Alpi di Morbegno (Morbegno's Society of Caricatori d'Alpe) was founded. The Society carried out important activities, including the building of a casera (a storage facility for the ageing of cheese, open to all associates) and various promotional initiatives that contributed to the Bitto's growing renown. The Society was dismantled in the years before WWII, when the management of the dairy was taken over by the municipality of Morbegno. In 1970, a Voluntary Bitto Cheese Consortium was constituted in Morbegno, with the support of Gerola's Pro Loco (a local non-profit association for local economic development and promotion). Composed of fifteen members, the Consortium defined the borders of the area of production, started branding the cheese wheels with the Bitto name, and reintroduced Morbegno's dairy fair. The Consortium represented a first attempt to create a Bitto GI, even if, due to the voluntary nature of the organisation, production methods were entrusted to the member's good faith rather than based on legally binding guidelines. Participation to the fair was initially open to Consortium members only, but was later extended to other cheese producers.

During the 1970s, the overall production of Bitto and Bitto-like cheese decreased as a result of the modernisation processes affecting mountain life. The drop in production in the original territory and the general crisis of alp cheese contributed to a further expansion of the Bitto production area. In this context, in 1983 the Chamber of Commerce, Industry and Agriculture (CCIA) of Sondrio created the Valtelline collective brand. Under its umbrella, various denominations were created, including Bitto, to be used only for cheese produced in the Bitto 
Valleys; Valtellina d'Alpe, for cheese made in other high mountain pastures during the summer; and Casera, a cheese produced throughout the year. The area of production of all these cheeses corresponded to the entire Sondrio province with the exception of Bitto, whose production territory was limited to the Bitto Valleys. The distinction between Bitto and other alp cheeses underlined the excellence of the former.

In the same years, the Consortium changed its internal organisation. With the support of the CCIA and Colavev (the Consortium of Valtellina and Valchiavenna dairies), it abandoned its voluntary nature becoming a formal organisation. The Consortium promoted the development of the Bitto Producers Cooperative, which bought wheels from producers and handled their aging, and started the process to obtain a PDO recognition. At the same time, it encouraged the extension of Bitto's production area to the entire province of Sondrio, promoting the transfer of knowledge related to Bitto production to other areas of Valtellina and the nearby Valchiavenna (where Bitto-like cheese had not been previously produced). In April 1995, Bitto obtained the PDO status; as a result, the new Consortium of Valtellina Casera and Bitto (hereafter CTCB) was founded. The approved product specification introduced significant changes to traditional Bitto making processes. First, the PDO guidelines enlarged the production area to the entire Sondrio's province, removing the distinctions previously made under the Valtellina brand; this extension was justified with the idea that it would have been hard to obtain a PDO protection given the small volumes of heritage Bitto production. Second, production process did not require production in Alpine pastures during the summer. Finally, the percentage of goat milk allowed was reduced from the traditional $20-30 \%$ to $10 \%$ only, with an option of not using goat milk at all. PDO specifications also permitted the use of animal 
fodder and enzymes and introduced various other provisions that overall represented a remarkable deviation from tradition.

The PDO provisions reflected a balance of power in favour of the producers localised outside of the Bitto Valleys. Indeed, thanks to the new specifications, in the years that followed the production of the Consortium increased and the numbers of Bitto wheels went from 5,700 in 1996 up to 27,000 in 2004 , and since 2009 has consistently remained in the 20,000 wheels range. Some Bitto Valleys producers, however, were not happy with the new specification. In 1994, they founded a Bitto Committee to safeguard the historical production method and area. The following year, the Rebels (as they started being known) did not take part in the Morbegno fair, to denounce the lack of a cheese contest category especially dedicated to 'historical' Bitto. Slow Food sided with the Rebels who, in 2002, had turned the Bitto Committee into the Società Produttori Valli del Bitto (Bitto Valleys Producer Society), and in 2003 established the Historical Bitto Presidium that involved 16 producers. In 2003, the Società Valli del Bitto Trading spa (Bitto Valleys Trading Stock Company) was constituted to buy cheese at fair prices from producers and takes care of commercialisation; the stock company form was chosen to facilitate the acquisition of shareholders (only members of the Bitto supply chain would have been able to join a cooperative). From the perspective of Slow Food, Bitto was an emblematic case of the battle the movement was conducting against mainstream agrobusiness producers. By supporting the Rebels, Slow Food was thus advancing its own institutional goals by showing that a rebellion was indeed possible, thus inspiring other smaller producers to do the same.

In 2004, a truce was called: Rebels obtained to compete alone in an especially dedicated cheese contest category at the Morbegno fair, and were allowed to differentiate their products through 
a Bitto Valli del Bitto (Bitto Valleys' Bitto) label. The relationship between CTCB and the Rebels kept however being tense. In 2005, increasingly supported by the public opinion, the Rebels abandoned the Consortium, to be back in 2007 in occasion of the centenary anniversary of the Morbegno fair. The same year, the Società Valli del Bitto Trading spa created a casera (cheese storage facility) on a site owned by the municipality of Gerola with a privately funded investment of $€ 300,000$. The on-again/off-again relationship continues for various years. In October 2009, the Rebels got fined by the Ministry for Agricultural, Alimentary and Forestry Policies for an amount of $€ 60,000$ for not having undergone the PDO controls and for the usurpation of the Bitto protected denomination. Commentators considered the situation paradoxical: producers using traditional methods and localised in the Bitto Valley were no longer allowed to use the Bitto trademark for their cheese. In 2010, the Consorzio Salvaguardia Bitto Storico (Consortium for the Safeguard of Historical Bitto) was created. In 2014, the Consortium and the CTCB announced a "Bitto peace" in occasion of the Expo 2015 in Milan: with the support of the CCIA of Sondrio, the two consortia signed an agreement that recognised the existence of two different production models and presented themselves together at EXPO 2015 and other promotional events such as the Morbegno fair and the Salone del Gusto in Turin.

The "Bitto peace" did not however last long. During the negotiations with the PDO, mediated by the CCIA of Sondrio and the Lombardy Region, the Rebels also asked for a public contribution to compensate the private investments they had sustained to build the casera in Gerola, which was denied. In 2016, confronted with the lack of changes in the PDO specifications and the risks of new fines related to the use of the Bitto name, again with the support of Slow Food the Rebels declared the so-called Bittexit. The Consortium pronounced Historical Bitto dead and in September, in occasion of the Salone del Gusto, adopted a new 
trademark, "Historical Rebel". At the end of 2016, the Valli del Bitto Trading Spa was turned in a benefit corporation (a new legal form established in Italy at the beginning of the year, whose goal is to benefit society and the environment) under the new name of Società Valli del Bitto spa benefit. To date, the Rebel consortium involves 12 heritage producers all of whom supply their products - a total of 3,000 wheels - to the Valli del Bitto Benefit Spa (trad. Bitto Valleys Benefit Stock Company). In contrast, the PDO consortium includes 55 producers for a total of about 19,580 wheels ${ }^{\mathrm{V}}$.

\section{Differentiating Heritage Bitto through a mediatised narrative of conflict}

Since the beginning, the conflict between the Rebels and the PDO consortium was highly mediatised: it did not remain an insiders' controversy behind closed doors, but rather a public question that from Valtelline kept hitting the national news. Warfare metaphors were prevalent in the Rebel's promotional activities as well as in journalistic accounts: the conflict between Rebels and the CTBC was framed as a war, a battle, a fight, even a 'dairy resistance' - a term recalling the Italian partisans' resistance movements during WWII. The Rebels were referred to as warriors, paladins, and even heroes - the latter term, in the broader Italian discourse, is often associated to farmers and artisan food producers who stick to traditional and labourintensive production methods in areas characterised by difficult geographical conditions preventing the adoption of contemporary technology. According to the Rebels, their fight was one opposing David to Goliath: small mountain farmers against an agribusiness lobby. The Rebels were not however exempt from critiques: they were considered by some anachronistic ('troglodytes who refuse modernity'; 'change is the hallmark of real tradition') and engaged in a self-interested fratricidal war that damaged fellow PDO Bitto producers and cast a negative light on all of Valtelline. Others dismissed the superiority of the Rebel's production methods, 
suggesting that also outside of the Bitto Valleys there were PDO producers who did not use industrial ferments or fodder. The Rebels - and those who supported them - replied by saying that the traditional Bitto's image was unduly extended to intrinsically dissimilar products, with the effect of misleading mainstream consumers unaware of the existence of two rather different varieties of Bitto. They also complained that the Consortium's promotional material reported a debatable Celtic etymology of the Bitto name (from 'Bitu', perennial), which weakened the link with the Bitto Valleys.

The Bitto wars thus received a heightened media visibility, which contributed not only to increase consumer awareness of, and curiosity towards, a cheese named Bitto - but also of the fact that there were important differences in production areas and methods between a small group of small, traditional producers and a majority of others who were deviating from tradition in important manners. Heritage Bitto, according to the Rebels, could only be made with grassfed cows' milk (no fodder) with the addition of $10-20 \%$ of Orobic goat milk, in alps at altitudes of 1,400-2,000 metres above sea level, during the summer, with warm milk, within 30 minutes of milking; wood should fuel the fire under the cauldron, adding to the cheese's final aroma; wooden utensils should be used, instead of steel or plastic ones, to help maintain and develop the milk's natural micro-flora and give the cheese specific sensory characteristics; no artificial ferments should be used; and the cheese should be dry-salted inside wooden moulds, to encourage the development of a more delicate rind and ensure better aging.

The Rebels thus adopted what in marketing literature is known as the underdog effect (Paharia et al., 2010): in other words, a branding strategy built around a narrative of conflict between smaller and underprivileged actors that rise up against powerful corporate foes. Playing the part 
of the underdog, the Rebels represented themselves as the positive heroes of a story increasingly supported by journalists, intellectuals, and more in general the public opinion. An online petition to safeguard traditional Bitto obtained in 2008 more than 3,500 signatures $^{\mathrm{VI}}$. The CTCB (and its supporting institutions) were instead framed as the negative heroes of the story - the 'bad guys'. Among the partners and allies, a key role was played by Slow Food, which used its considerable public influence to amplify the Rebels' story and turn traditional Bitto into a symbol of good, clean and fair food threatened by the mainstream agribusiness logics - and an inspirational story for other producers, showing that resistance was indeed possible. Slow Food also provided the Rebels with visibility and business contacts both domestically and internationally thanks to the two leading trade shows it organises: Cheese (Bra, Piedmont, 300,000 visitors in 2017) and Salone del Gusto (Turin, 220,000 visitors in 2018). At these events, the Bitto's story of rebellion was part of a larger narration of resistance in front of a sympathetic audience. The most important episode in the Bitto war - the one that received the most media attention - was the declaration of death of Historical Bitto that took place at the same time of the exit from the PDO Consortium (the so-called Bittexit, July 2016), followed by the announcement of the new name, Historical Rebel, at the Salone del Gusto (September 2016). The fact that heritage producers localised in the Bitto Valleys could no longer legally use the Bitto trademark was typically felt as an injustice and a paradox, contributing to cast an aura of sympathy to the Rebels.

An important element of the Rebel's storytelling strategy is the Bitto Centre in Gerola. Hosting the casera, a point of sale and a small restaurant, the Centre serves as an experiential showcase and a living reminder of the Bitto wars and the values Historical Rebel stands for. Tripadvisor reviews are extremely positive: the Center is considered a "rampart" and a "sanctuary" of the 
one true Bitto ("beware of imitations"), safeguarded thanks to the Rebels that fought the manoeuvrings of larger producers who appropriated its name. The casera, with its thousands of aging wheels of Bitto, is often deemed "spectacular" and able to create a sensorial and emotional involvement with the product. The staff, too, is appreciated for the passion and enthusiasm with which they tell the story of Bitto and its production methods. Product tastings complete the experience and allow for a greater sensorial appreciation of differences in Bitto of different ages and from different alps.

By highlighting functional differences and symbolically connoting their Bitto with tradition and resistance to mainstream agribusiness practices, Rebels were also able to legitimise the price differences between their version of Bitto and the Consortium's: "Behind these prices is the consecration of the difference between the industrial cheese of ferments and milk powder, and the cheese of master cheese makers, a difference unclear so far because the agrifood system did not want to make it known" (Corti, 2015). Tripadvisor reviews of Bitto Centre visitors mostly agree on the fact that heritage Bitto is "worth its price" once the production costs are considered, since "quality has its price". Today, on the Rebel's online store, the price of Historical Rebel is around $€ 35 / \mathrm{kg}$ for fresh Bitto (year 2018) which goes up to $€ 50 / \mathrm{kg}$ (year 2017) and $€ 120$ (year 2010). Some of the most aged wheels of historical Bitto have been auctioned over the years for record prices: in 2011, three wheels made in 1997, 1998 and 1999 were sold for a total of $€ 6,000$; in 2012, Bitto aged 15 years was sold at $€ 247 / \mathrm{Kg}$; in 2015 , a wheel of 15 years had been sold for $€ 163 / \mathrm{kg}$; in 2018 , a wheel of 18 years was sold for $€ 12,000$. These record prices, which earned heritage Bitto the title of one of the most expensive cheeses in the world, contribute to highlight its uniqueness but also to justify prices respect to PDO Bitto, whose retail price is in the range $€ 12-22 € / \mathrm{Kg}$. 
Like other Slow Food Presidia products, Historical Rebel can be criticised for its high price, which according to some represents an elitist approach to food production, since only a market niche of wealthy consumers can afford to taste it. Bitto Rebels respond to these complaints by leveraging on a trade fair logic that also considers the social and environmental externalities of other production models. The response to a Bitto Centre customer complaining against the outrageous price of Bitto in a Tripadvisor review was: "what is a right price? It's one that allows a producer to obtain an adequate compensation for his work, ... for the respect of traditions and the environment. An "absurd" or "crazy" price is one that is too low, so inexpensive to be unsustainable". Notably, the Società Valli del Bitto benefit spa pays its associate producers a wholesale price of $€ 16 / \mathrm{kg}$, which is remarkably higher than the one for PDO Bitto (in the range of $€ 8-12 / \mathrm{kgs}$, personal communication, 2018). A study carried out by Slow Food $(2013,2014)$ further reinforces promotional claims that heritage Bitto is characterised by high level of environmental, social and cultural sustainability. Even the change in name and legal form of the Società Valli del Bitto benefit spa in 2016 contributed to signal the ethical mission of the company. Introduced in the Italian legal system at the beginning of 2016, benefit corporations are for profit companies whose primary goal is to generate a positive social and environmental impact. The term 'trade' in the previous name, while coherent with the company's mission (cheese ageing and commercialisation), could be wrongly associated to the world of financial speculation. The number of non-producer shareholders (110 in 2018) has been increasing despite the fact that the company has yet to distribute profits - a sign that capital subscription is mostly motivated by ethical, rather than economic, considerations. 
The market confusion between the two Bitto cheeses is however far from being dispelled. We noted for example news article about Historical Rebel that report pictures of PDO Bitto. At least one PDO producer sells its Bitto in its online store at a price that is similar to that of Historical Rebel, possibly to take advantage of consumers that do not know the difference between the two cheeses.

\section{Discussion and Conclusion}

This study reconstructed the history of the Bitto wars, which opposed groups of producers with different claims to a GI's boundaries and product specifications. Thanks to a longitudinal case study approach, we showed that the Rebels' highly mediatised actions were framed - by the Rebels themselves and by sympathetic commentators - as a narrative of war that climaxed with their decision to leave the PDO Consortium slamming the door. Our study not only reconstructed the dynamics of the war - the various moves and countermoves that took place over a period of decades - but also its promotional uses. We found that mediatised conflict can be the base of a differentiation strategy aimed not only at highlighting functional differences but also, to some extent, constructing symbolic differences between groups of producers inside GIs.

We are certainly not the first to find evidence of tensions and conflicts in GIs (Moity Maïzi and Bouche, 2011; Di Fonzo and Russo, 2015; Amilien and Kjærnes, 2017). We contribute to this literature by suggesting that smaller, heritage producers are particularly at risk of being marginalised as the boundaries of production areas are extended and larger and more industrialised producers gain influence inside producer collectives. We also highlight a previously unexplored outcome of conflict - secession, or the formal exit from a GI consortium 
- which shows that producers (individually or as a group) are dynamically subject to both centripetal and centrifugal forces as they evaluate whether or not (keeping on) adhering to the collective strategy behind a GI (Moity Maïzi and Bouche, 2011). Future research should pay more attention to the heterogeneous distribution of costs and benefits among adhering members, as well as the governance mechanisms that are put in place to ensure adequate levels of representation in collective decision-making. This paper contributes to research in this perspective highlighting that smaller/larger production areas, more/less traditional production methods (see again Figure 1) and the recognition of different quality levels are possible determinants of conflict inside GIs. In terms of the generalisability of our research findings, the case was purposively chosen as characterised by conditions more likely to generate conflict. We speculate that Bittexit could have been prevented had the Rebels obtained symbolic and/or material recognition for their smaller but more heritage-consistent production. Future research should examine other factors likely to alleviate or aggravate conflicts.

More in general, our study contributes to literature on controversies in localised agrofood systems by introducing the notion of competitive wars, which are a form of heightened authenticity-protecting conflicts (Husemann and Luedicke, 2013). Controversies do not necessary result in wars. Differences in opinions can be met with open-minded consideration and incorporated, or faced with closemindedness and rejection, thus originating destructive conflicts (Tjosvold, 1985). Competitive wars are periods of intensified controversies and conflicts that can be understood as rhetorical games through which contenders aim to mobilise the support of key constituencies in their favour, highlighting each other's weaknesses (Rindova et al., 2004). Contrary to expectations, in the case we studied smaller and more disadvantaged producers (the underdogs) were able to obtain the sympathies of the public 
opinion and other relevant stakeholders and target a market segments constituted by consumers willing to pay a premium price for their products. A contribution of our study is that the mediatised narration of conflict can contribute to raise consumer awareness, differentiate products, and result in symbolic value creation. Wars such as the one we studied can however generate both positive and negative impacts. Positive outcomes for the Rebels included, at the cultural level, the safeguarding of their know-how and traditional production methods; at the social level, a sense of cohesion; and, at the business level, a clearer marketing positioning as well as the possibility to charge higher prices that compensate higher production costs. Negative impacts have in the case we studied included personal stress, the severing of social ties, legal troubles and expenses, the giving up of the benefits coming from belonging to a larger producer collective and the possibility to legally use their historical brand name. When deciding whether or not embarking in a war, we recommend that a prudential cost/benefit analysis is carried out, as fortune do not necessarily favour the bolds.

Our study contributes to a better understanding of the image effect of products protected by GIs, considered of quality (Hoffmann, 2000, van Ittersum et al., 2003; Mérel and Sexton, 2012) and more traditional and authentic (Tregear et al., 2007). Symbolic associations such as authenticity, respect of tradition, and a link to a given territory find their origin in cultural epicentres (in our case, the Bitto valleys). When GIs boundaries are enlarged, these associations are transferred to other producers, who benefit economically from these associations without having contributed to create them. Put differently, heritage producers localised in cultural epicentres create image externalities that can benefit the entire producer collective behind a GI. Heritage brands routinely transfer the image of their top products to less expensive product lines. A remarkable example is the fine fashion business, where brands with a strong heritage 
such as Chanel and Dior run haute couture collections at a loss to generate the image externalities that permit them sell at premium price prêt-à-porter clothing and accessories; losses in haute couture are considered branding investments. In these cases, these image transfers occur inside the same company. In the case of GIs, image externalities are generated by some firms and exploited by others, and the costs and benefits of these image externalities are unevenly distributed. Based on this understanding of image transfers inside producer collectives, forms of compensations to heritage producers are not unthinkable. Product specifications allowing for different quality levels are a means to provide heritage producers with a symbolic recognition and justify the premium price of their products. Other producers who might represent the majority of a GI consortium - might resist this solution, fearing that it might cast a negative light on their products as second-class alternatives. Future research should evaluate whether these fears are justified.

These considerations have broader policy implications. GIs are often supported, at the policy and local level, as a rural development tool, particularly in the context of less favored or marginal areas (Bowen, 2010; Belletti, Marescotti and Touzard, 2017). One of the reasons why product specifications with extended areas and not-so-traditional production methods (see again our figure 1) might be supported at the policy level is that they might diffuse economic benefits to a larger area, thus contributing to rural development. A larger number of GI members can also generate more financial resources for marketing communications. Yet, our study highlights that economic these economic outcomes might sometimes be at odd with the safeguarding of heritage producers' traditional know-how. Geographical indications are not only trademarks, but also legal devices to protect producers' intellectual property rights (see, among others, Okedui, 2007). Traditional producers in core areas may abandon ancestral production 
techniques in favour of industrialized products and their local specificities might be watered down when production areas are extended. As the case of Bitto shows, producer controversies over authenticity can trigger consumer reactions, and at a time where social media-enabled consumer boycotts are increasingly frequent (Klein, Smith and John, 2004), policy makers at the supra-national, national and local level can too be the targets of heightened public criticism. GI policies should therefore carefully balance economic and cultural safeguarding goals. A good solution in this respect might be the creation of specifications that allow for products with different levels of heritage-sensitiveness.

Our study hints at the role of trade fairs and experiential showcases as immersive tools for storytelling and taste education. Selecting the right trade fair is a key challenge for exhibiting firms. Competition between these events often reflects the underlying competition between groups of producers from different areas or with different production philosophies (Bathelt et al., 2014). In our study, the Rebels' stopped exhibiting at the Morbegno dairy fair as their heritage Bitto was presented together with other "Bitto-like" products in ways that made it difficult to highlight their specificities and justify their premium price. Producers like the Rebels should instead present themselves at trade fairs, such as the Slow Food-organised Cheese and Salone del Gusto, where their experiential storytelling can take place together with producers who tell similar stories of respect of tradition and rebellion to agribusiness logics, in a way to attract the right market segment. Experiential showcases like the Bitto Centre can also serve as learning environments that permit to tell stories about a product and its production methods in spectacular, engaging, and credible manners, thus contributing to product meaning generation. Respect to temporary promotional events, permanent showcases contribute to the establishment of territorial legitimacy, or the legitimacy that is gained by being physically 
instantiated in some form (Humphreys, 2010). The appropriate promotional mix for GI producers has received limited attention so far. We recommend that both permanent and temporary showcases should be part of their marketing communication strategy.

\section{Notes}

['] www.formaggiobitto.it

[II] https://www.facebook.com/StoricoRibelle/

[II] https://ribellidelbitto.blogspot.com

$\left[{ }^{\mathrm{IV}}\right]$ https://www.tripadvisor.it/Attraction_Review-g1596429-d2290971-Reviews-

Centro_del_Bitto_Storico_Ribelle-Gerola_Alta_Province_of_Sondrio_Lombardy.html

$[\mathrm{V}]$ https://Www.clal.it/index.php?section=-bitto\#produzioni

$\left.{ }^{\mathrm{VI}}\right]$ https://firmiamo.it/probittostorico\#petition

\section{References}

Addor, F. and Grazioli, A. (2002), "Geographical indications beyond wines and spirits", The Journal of World Intellectual Property, Vol. 5 No. 6, pp. 865-97.

Addor, F., Thumm, N. and Grazioli, A. (2003), Geographical indications: important issues for industrialized and developing countries. European Commission, Luxembourg.

Agostino, M. and Trivieri, F. (2014), "Geographical indication and wine exports. An empirical investigation considering the major European producers”, Food Policy, Vol. 46, pp. 22-36.

Allaire, G., Casabianca, F. and Thévenod-Mottet, E. (2011), "Geographical origin: a complex feature of agro-food products", in Barham, E. and Sylvander, B. (Eds), Labels of Origin for Food: Local Development, Global Recognition, CABI, Wallingford, pp. 1-12.

AlpFoodway (2018), "Deliverable T2.1.1: Map of ICH Commercial Valorisation Practices", available at: http://www.alpine-space.eu/projects/alpfoodway/en/projectresults/downloads/wp2-marketing (accessed September 21, 2018)

Amilien, V. and Kjærnes, U. (2017), "The dynamics of sheep welfare in Norway-between idealised images and practical realities", British Food Journal, Vol. 119 No.4, pp.952-966.

Arnould E.J., Thompson C.J. (2005), "Consumer Culture Theory (CCT): Twenty Years of Research", Journal of Consumer Research, Vol. 31 No.4, pp. 868-882.

Bathelt, H., Golfetto, F. and Rinallo, D. (2014), Trade Shows in the Globalizing Knowledge Economy, Oxford University Press, Oxford. 
Belletti, G., Marescotti, A., and Touzard, J.-M. (2017), "Geographical indications, public goods, and sustainable development: The roles of actors' strategies and public policies", World Development, Vol. 98, pp. 45-57.

Boisseaux, S. (2012), Les appellations d'origine et indications géographiques en Suisse, 1990-2006: politisation, institutionnalisation, nouveaux pouvoirs, Analyse des politiques publiques $=$ Politik analyse, Rüegger, Zurich.

Boisseaux S., Leresche J.P. (2002), "Dynamiques régionales et globalisation: le cas de la politique des AOC-IGP en Suisse", Revue Suisse de Science Politique, Vol. 8 No. 3-4, pp. 3560 .

Boisseaux S. and Barjolle D. (2004), La bataille des AOC en Suisse. Les appellations d'originecontrôlées et les nouveaux terroirs, Presses Polytechniques et Universitaires Romandes (PPUR), Lausanne.

Bowen, S. (2010), "Embedding local places in global spaces: geographical indications as a territorial development strategy", Rural Sociology, Vol. 75 No. 2, pp. 209-243.

Bruner, J. (2004), "Life as narrative", Social research: An international quarterly, 71(3), pp.691-710.

Corti, M. (2011), I ribelli del bitto: Quando una tradizione casearia diventa eversiva, Slow Food Editore, Bra.

Corti, M., De La Pierre, S., Agostini, S. (2015), Cibo e identità local: Sistemi agroalimentari e rigenerazione di comunità. Sei esperienze lombarde a confronto, Centro Studi Valle Imagna, Bergamo.

Corti, M., Ruffoni, C. (2009), Il formaggio Val del Bitt: La storia, gli uomini, gli alpeggi. Come nasce un mito caseario, Ersaf Regione Lombardia, Milano.

Di Fonzo, A. and Russo, C. (2015), "Designing geographical indication institutions when stakeholders' incentives are not perfectly aligned", British Food Journal, Vol. 117 No.10, pp.2484-2500.

Eden, S., Bear, C., Walker, G. (2008), "The sceptical consumer? Exploring views about food assurance", Food Policy, Vol. 33 No. 6, pp.624-630.

Escalas, E.J. (2004), "Narrative processing: Building consumer connections to brands", Journal of Consumer Psychology, Vol. 14 No.1-2, pp.168-180.

Grasseni, C. (2011), "Re-inventing food: Alpine cheese in the age of global heritage", Anthropology of food, Vol. 8.

Grasseni, C. (2012), "Resisting cheese. Boundaries, Conflict and Distinction at the foot of the Alps", Food. Culture and Society, Vol.15 No.1, pp. 23-29. 
Grasseni, C. (2017), The Heritage Arena. Reinventing Cheese in the Italian Alps Food, Nutrition, And Culture, Oxford: Berghahn Books, New York.

Heath, J. and Potter, A. (2004), The rebel sell: Why the culture can't be jammed, HarperCollins, New York.

Hirschman, A.O., (1970), Exit, voice, and loyalty: Responses to decline in firms, organizations, and states, Vol. 25, Boston, MA: Harvard university press.

Hoffmann, R. (2000), "Country of origin: a consumer perception perspective of fresh meat", British Food Journal, Vol. 102 No. 3, pp. 211-229.

Holt, D.B. (2003), Brands and branding, Boston, MA: Harvard Business School.

Humphreys, A. (2010), "Semiotic structure and the legitimation of consumption practices: The case of casino gambling”, Journal of Consumer Research, Vol. 37 No 3, pp. 490-510.

Husemann, K.C. and Luedicke, M.K. (2013), "Social conflict and consumption: A metaanalytical perspective," Advances in Consumer Research, Vol. 41, pp. 355-360.

Husemann, K.C., Ladstaetter, F. and Luedicke, M.K. (2015), "Conflict culture and conflict management in consumption communities", Psychology \& Marketing, Vol. 32 No. 3, pp. 265-284.

Jones, J., Shears, P., Hillier, D., Comfort, D. and Lowell, J. (2003), "Return to traditional values? A case study of Slow Food”, British Food Journal, Vol. 105 No. 4-5, pp. 297-304.

Keller, K.L. (2003), "Brand synthesis: The multidimensionality of brand knowledge", Journal of consumer research, Vol. 29 No.4, pp.595-600.

Klein, J.G., Smith, N.C., and John, A. (2004), "Why we boycott: Consumer motivations for boycott participation", Journal of Marketing, Vol. 68 No. 3, pp. 92-109.

Krystallis, A. and Ness, M. (2005), "Consumer preferences for quality foods from a South European perspective: a conjoint analysis implementation on Greek olive oil", The International Food and Agribusiness Management Review, Vol. 8 No. 2, pp. 62-90.

Luedicke, M.K., Thompson, C.J. and Giesler, M. (2010), "Consumer identity work as moral protagonism: How myth and ideology animate a brand-mediated moral conflict," Journal of Consumer Research, Vol. 36 No. 6, pp. 1016-1032.

Lyons H., (2005) "Food industry case studies: a suitable medium for publication", British Food Journal, Vol. 107 No. 9, pp.702-713.

Maïzi, P.M. and Bouche, R. (2011), "Ancrage territorial et hybridation des savoir-faire au sein d'un système agroalimentaire localisé. Le cas des fromages corses", Économie rurale. Agricultures, alimentations, territoires, Vol. 322, pp.24-38.

Mérel, P.R. and Sexton, R.J. (2012), "Will geographical indications supply excessive 
quality?", European Review of Agricultural Economics, Vol. 39 No. 4, pp. 567-587.

McCracken G. (1986), "Culture and Consumption: A Theoretical Account of the Structure and Movement of the Cultural Meaning of Consumer Goods", Journal of Consumer Research, Vol.13 No.2, pp. 71- 84.

Muniz, A.M. and O'guinn, T.C. (2001), "Brand community”, Journal of consumer research, Vol. 27 No. 4, pp.412-432.

Okedui, R.L. (2007), “The international intellectual property roots of geographical indications", Chicago-Kent Law Review, Vol. 82, No. 3, pp. 1329-1365.

Paharia, N., Avery, J. and Keinan, A. (2014), "Positioning brands against large competitors to increase sales”, Journal of Marketing Research, Vol. 51 No. 6, pp. 647-656.

Paharia, N., Keinan, A., Avery, J. and Schor, J.B. (2010), "The underdog effect: The marketing of disadvantage and determination through brand biography", Journal of Consumer Research, Vol. 37 No. 5, pp.775-790.

Park, C.W., Jaworski, B.J. and Maclnnis, D.J. (1986), "Strategic brand concept-image management", The Journal of Marketing, Vol. 50 No.4, pp.135-145.

Porter, M.E. (1985), Competitive advantage: Creating and sustaining superior performance, New York: The Free Press.

Rangnekar, D. (2004), “The socio-economics of geographical indications. UNCTAD-ICTSD Project on IPRs and Sustainable Development, Issue Paper, 8, pp.13-15.

Rindova, V.P., Becerra, M. and Contardo, I. (2004), "Enacting competitive wars: Competitive activity, language games, and market consequences", Academy of Management Journal, Vol. 29 No. 4, pp. 670-686.

Schouten, J.W. and McAlexander, J.H. (1995), "Subcultures of consumption: An ethnography of the new bikers", Journal of consumer research, Vol. 22 No.1, pp.43-61.

Siniscalchi, V. (2013), "Slow versus Fast: Economie et écologie dans le mouvement Slow Food”, Terrain, Vol. 60, pp. 132-147.

Stake, R.E. (1995), The art of case study research, Sage Publications, London.

Tell, J., Hoveskog, M., Ulvenblad, P., Ulvenblad, P.O., Barth, H. and Ståhl, J. (2016), "Business model innovation in the agri-food sector: a literature review", British Food Journal, Vol. 118 No. 6, pp. 1462-1476.

Tjosvold, D. (1985), "Implications of controversy research for management.", Journal of Management, Vol. 11 No.3, pp. 21-37.

Tregear, A., Arfini, F., Belletti, G. and Marescotti, A. (2007), "Regional foods and rural development: the role of product qualification", Journal of Rural Studies, Vol. 23 No. 1, pp. 
$12-22$.

Ubertazzi, B. (2017), "EU geographical indications and intangible cultural heritage", IIC International Review of Intellectual Property and Competition Law, Vol. 48 No. 5, pp. 562587.

Van de Kop, P., Sautier, D. and Gerz, A. (2006), “Origin based products: Lessons for propoor market development", Bulletin/Development Policy and Practice No. 372, KIT Publishers, Royal Tropical Institutue, Amsterdam.

van Ittersum, K., Candel, M.J.J.M. and Thorelli, F. (1999), “The market for PDO/ PGI protected regional products: consumer attitudes and behaviour", in the proceeding of the 67 th EAAE Conference, Le Mans, France, 1999, pp 209-221.

van Ittersum, K., Meulenberg, M.T.G., van Trijp, H.C.M. and Candel, M.J.J.M. (2007), "Consumers' appreciation of regional certification labels: a Pan-European study", Journal of Agricultural Economics, Vol. 58 No. 1, pp. 1-23.

Vandecandelaere, E., Arfini, F., Belletti, G. and Marescotti, A. (2010), Linking People, Places and Products: A Guide for Promoting Quality Linked to Geographical Origin and Sustainable Geographical Indications, 2nd ed., FAO, Rome.

Wall, J. A., \& Callister, R. R. (1995), "Conflict and its management", Journal of Management, Vol. 21 No.3, pp. 515-558.

Yin, R.K. (2014), Case study research. Design and methods, 5th ed., Sage Publications, London.

\section{Further reading}

European Parliament (2012), "Regulation (EU) No 1151/2012 of the European Parliament and of the Council of 21 November 2012 on quality schemes for agricultural products and foodstuffs", Official Journal of the European Union, L 343/1, 14 December, available at: http://data.europa.eu/ eli/reg/2012/1151/oj (accessed January 30, 2018).

Slow Food (2013), "Slow Food Presidia in Europe: A Model of Sustainability. An assessment of the sociocultural, agri-environmental and economic results: 2000-2012", available at: https://www.slowfood.com/sloweurope/en/topics/biodiversita/ (accessed September 15, 2018)

Slow Food (2014), "Slow Food Presidia and Sustainable Development", available at: http://www.slowfood.com/sloweurope/wp-content/uploads/ENG-risultati-pres--di.pdf (accessed September 13, 2018) 
Fig.1 GIs' product specifications: a conceptual framework

Production Methods

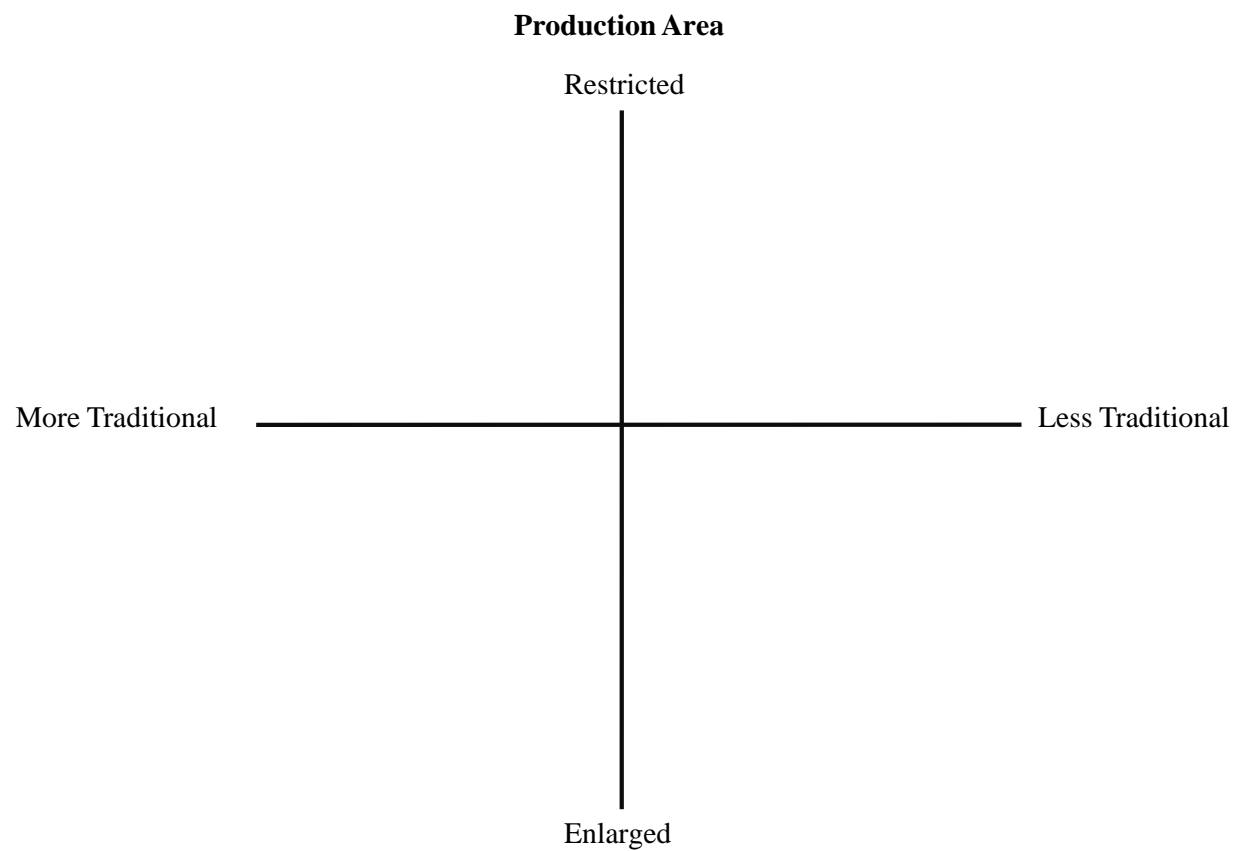


Table 1 - Summary of Main Data Sources

\begin{tabular}{|c|c|c|c|}
\hline Typology & Sources & Data Set & Main Purpose of usage \\
\hline $\begin{array}{l}\text { Academic work } \\
\text { on Bitto }\end{array}$ & Books, academic articles & $\begin{array}{l}3 \text { Books } \\
14 \text { Articles }\end{array}$ & $\begin{array}{l}\text { - Reconstruction of the history } \\
\text { of the Bitto cheese, from ancient } \\
\text { times to more recent } \\
\text { developments }\end{array}$ \\
\hline $\begin{array}{l}\text { Media Coverage } \\
\text { of the Bitto wars }\end{array}$ & $\begin{array}{l}\text { Local and national } \\
\text { newspapers } \\
\text { Food magazines and } \\
\text { portals }\end{array}$ & $\begin{array}{l}\text { Local press: } 126 \text { articles } \\
\text { National press: } 57 \\
\text { Food } \\
\text { magazines/portals: } 34\end{array}$ & $\begin{array}{l}\text { - Reconstruction of key facts in } \\
\text { the recent history of the Bitto } \\
\text { Cheese } \\
\text { - Analysis of how key observers } \\
\text { made sense of the conflicts } \\
\text { around Bitto }\end{array}$ \\
\hline $\begin{array}{l}\text { Bitto Rebels } \\
\text { online } \\
\text { promotional } \\
\text { sources }\end{array}$ & $\begin{array}{l}\text { Official Website, Blog, } \\
\text { Facebook } \\
\text { Instagram Profile }\end{array}$ & $\begin{array}{l}1 \text { web site } \\
117 \text { blog posts } \\
800 \text { Facebook posts } \\
79 \text { Instagram posts }\end{array}$ & \multirow{3}{*}{$\begin{array}{l}\text { - Identification of the Rebels' } \\
\text { storytelling strategy and key } \\
\text { differences highlighted between } \\
\text { Historical and Consortium Bitto } \\
\text { - Identification of key moments } \\
\text { in the life of the Rebel's } \\
\text { associations }\end{array}$} \\
\hline $\begin{array}{l}\text { Bitto Rebels } \\
\text { online interviews }\end{array}$ & $\begin{array}{l}\text { Local/National } \\
\text { Televisions and Youtube } \\
\text { Channels }\end{array}$ & $\begin{array}{l}15 \text { video interviews, } \\
\text { total }>70\end{array}$ & \\
\hline $\begin{array}{l}\text { Personal } \\
\text { Interviews }\end{array}$ & $\begin{array}{l}\text { Representatives of the } \\
\text { Bitto Rebels }\end{array}$ & $\begin{array}{l}2 \text { Interviews, }>1 \mathrm{~h} \text { each, } \\
\text { and various follows-up }\end{array}$ & \\
\hline $\begin{array}{ll}\text { Slow } & \text { Food } \\
\text { material } & \end{array}$ & $\begin{array}{l}\text { Slow Food's Foundation } \\
\text { for Biodiversity's } \\
\text { Slow Food's study on the } \\
\text { sociocultural, agri- } \\
\text { environmental and } \\
\text { economic results of Slow } \\
\text { Food Presidia }\end{array}$ & $\begin{array}{l}\text { Entry on the Historical } \\
\text { Bitto Presidium } \\
\text { Evaluation of Historical } \\
\text { Bitto Presidium } \\
\text { performances }\end{array}$ & $\begin{array}{l}\text { - Identification of Slow Food's } \\
\text { involvement in the safeguarding } \\
\text { of Historical Bitto } \\
\text { - Better understanding of the } \\
\text { Presidium's economic, social, } \\
\text { and cultural impacts. }\end{array}$ \\
\hline $\begin{array}{l}\text { Field observation } \\
\text { of the Rebels' } \\
\text { promotional } \\
\text { events }\end{array}$ & $\begin{array}{l}\text { Observation at two trade } \\
\text { fairs (Cheese, Bra, 20- } \\
\text { 23.9.2017; Salone del } \\
\text { Gusto, Turin, } 20- \\
24.9 .2018)\end{array}$ & $\begin{array}{l}\text { Field observation of the } \\
\text { Historical Bitto } \\
\text { Presidium stand and } \\
\text { activities: } 10 \mathrm{~h} \text { in total, } \\
50 \text { pictures, informal } \\
\text { interviews with vendors } \\
\text { and clients }\end{array}$ & $\begin{array}{l}\text { - Identification of the Rebels' } \\
\text { storytelling strategy in the } \\
\text { context of promotional } \\
\text { experiences } \\
\text { - Identification of visitors and } \\
\text { clients' reactions }\end{array}$ \\
\hline $\begin{array}{l}\text { Tripadvisor } \\
\text { reviews }\end{array}$ & Tripadvisor & $\begin{array}{l}66 \text { Reviews of the } \\
\text { Historical Bitto Center }\end{array}$ & $\begin{array}{l}\text { - Identification of visitors' } \\
\text { reactions to the Historical Bitto } \\
\text { Center' experience, with a } \\
\text { particular focus on perceived } \\
\text { authenticity and the legitimacy } \\
\text { of price levels. }\end{array}$ \\
\hline $\begin{array}{l}\text { Prices of PDO and } \\
\text { Historical Bitto }\end{array}$ & $\begin{array}{l}\text { Various online and brick } \\
\text { and mortar retailers } \\
\text { (direct observations, } \\
\text { phone calls) }\end{array}$ & $\begin{array}{l}\text { Historical Bitto (1): } \\
\text { Rebel's website and } \\
\text { personal interviews }\end{array}$ & $\begin{array}{l}\text { - Evaluation of price differences } \\
\text { between PDO Bitto and } \\
\text { Historical Rebel }\end{array}$ \\
\hline
\end{tabular}

